\title{
METAMITRON REPLACING CARBARYL IN POST BLOOM THINNING OF APPLE TREES ${ }^{1}$
}

\author{
JOSÉ LUIZ PETRI ${ }^{2}$, MARCELO COUTO ${ }^{3}$, GENTIL CARNEIRO GABARDO ${ }^{4}$, \\ POLIANA FRANCESCATTO ${ }^{5}$, FERNANDO JOSÉ HAWERROTH ${ }^{6}$
}

\begin{abstract}
Carbaryl or the mixture of carbaryl with NAA (naphthalene acetic acid) or BA (benzyladenine) are the post-bloom chemical thinners most widely used in apple thinning in Brazil. The marketing restriction of carbaryl demands new options of apple post-bloom thinners, requiring the evaluation of others compounds for this purpose. Metamitron is one of the substances that may be used in chemical thinning of apples. Metamitron was evaluated at two concentrations, alone or in mixture with BA, in 'MaxiGala', 'Fuji Suprema' and 'Fred Hough' apple cultivars. Applications of metamitron at $384 \mathrm{mg} \mathrm{L}^{-1}$ and at $768 \mathrm{mg} \mathrm{L}^{-1}$ in a mixture with BA, ranging from $40 \mathrm{mg} \mathrm{L}^{-1}$ to $80 \mathrm{mg} \mathrm{L}^{-1}$, sprayed on fruits with diameter ranging from 5 to $25 \mathrm{~mm}$ were compared with the standard treatment and hand thinning. The experimental design was a randomized complete block with 4-6 repetitions of a single plant. The variables analyzed were: fruit set (\%); percentage of floral clusters with 1, 2, 3, 4 or more fruits; fruit yield $(\mathrm{kg})$; average fruit fresh mass $(\mathrm{g})$ and percentage of dropped fruit after thinning. Metamitron alone or in combination with BA reduced production per plant and significantly increased the fresh weight of fruits in all cultivars tested. Metamitron at $800 \mathrm{mg} \mathrm{L}^{-1}$ resulted in excessive fruit thinning, especially in 'MaxiGala' cultivar. Metamitron or metamitron + BA have potential to compose the program of chemical thinning of apple trees to replace carbaryl.
\end{abstract}

Index terms: Plant growth regulators, concentration, fruit set, fruit production.

\section{METAMITRON COMO SUBSTITUTO DO CARBARYL NO RALEIO PÓS FLORAÇÃO DA MACIEIRA}

RESUMO- O carbaryl ou a mistura de carbaryl com ANA (ácido naftaleno acético) ou BA (Benziladenina) são os produtos mais utilizados no raleio químico da macieira no Brasil. Com o cancelamento do registro do carbaryl como raleante de pós-floração, são necessárias novas alternativas, sendo importante testar diferentes raleantes com esta finalidade. Dentre as substâncias passíveis de utilização no raleio da macieira insere-se o metamitron. O objetivo deste estudo foi avaliar a resposta da aplicação de metamitron no raleio das macieiras 'Fuji Suprema', 'MaxiGala' e 'Fred Hough'. O uso de metamitron foi testado em duas concentrações, só ou em mistura de tanque com BA, e comparado com BA e BA + etefom, em três cultivares de macieira: 'Maxigala', 'Fuji Suprema' e 'Fred Hough'. Aplicações de $384 \mathrm{mg} \mathrm{L}^{-1}$ e $768 \mathrm{mg} \mathrm{L}^{-1}$ de metamitron em mistura com BA de $40 \mathrm{mg} \mathrm{L}^{-1}$ e $80 \mathrm{mg} \mathrm{L}^{-1}$ aplicado em frutos de 5 a $25 \mathrm{~mm}$ de diâmetro foram comparadas com 'tratamento-padrão' e raleio manual. Foi usado o delineamento experimental em blocos ao acaso com cinco a seis repetições. As variáveis analisadas foram: frutificação efetiva (\%), percentagem de cachos florais com $1 ; 2 ; 3 ; 4$ ou mais frutos por inflorescência, produção por planta $(\mathrm{kg})$, número de frutos por planta, massa média dos frutos $(\mathrm{g})$ e percentagem de queda de frutos após o raleio. O metamitron só, ou em combinação com BA, reduziu a produção por planta e aumentou a massa média dos frutos em todas as cultivares estudadas. Metamitron a $768 \mathrm{mg} \mathrm{L}^{-1}$ resultou em excessivo raleio, especialmente na 'MaxiGala'. Metamitron ou metamitron + BA tem potencial para compor o programa de raleio químico da macieira em substituição ao carbaryl.

Termos para indexação: Regulador de crescimento, concentração, frutificação efetiva, produção.

\footnotetext{
1(Paper 146-15). Received May 28, 2015. Accepted May 18, 2016.

${ }^{2}$ Agronomist, M.Sc. Researcher Epagri - Experimental Station of Caçador. P.O.box 591. 89500-000, Caçador - SC, Brazil. E-mail: petri@epagri.sc.gov.br

${ }^{3}$ Agronomist, D.Sc. Researcher Epagri - Experimental Station of Caçador. P.O.box 591. 89500-000, Caçador - SC, Brazil. E-mail: marcelocouto@epagri.sc.gov.br

${ }^{4}$ Agronomist, Academic, at master's level, of the Post-Graduate Program in Plant Production. CAV/UDESC, Lages - SC, Brazil. E-mail: ge.gabardo@gmail.com

${ }^{5}$ Agronomist, D.Sc. Cornell University - Ithaca, NY, United States of America. E-mail: polianafran@yahoo.com.br

${ }^{6}$ Agronomist, D.Sc., Researcher, Embrapa Uva e Vinho, 95700-000, Bento Gonçalves - RS, Brazil. E-mail: fernando.hawerroth@ embrapa.br
} 


\section{INTRODUCTION}

Reduce fruit set, particularly in years when climatic conditions of the previous year favored excessive floral induction, is necessary to regulate production and increase fruit size and quality. Thinning is an important technique as it reduces the number of fruits per plant, significantly improving the quality of the remaining fruits.

Chemical thinning may be adopted to replace hand thinning to reduce labor costs, since this practice enables the removal of excess fruits, adjusting the productive capacity of plants and consequently preventing alternate beating, since floral induction occurs concurrently with intense cell division and initial fruit growth (BANGERTH, 2006; FRANCESCATTO, 2014). Furthermore, the fixing of four or more fruit per inflorescence hinders hand thinning.

The products used for the chemical fruit thinning can be applied prior to blooming, during blooming or in the post-bloom period. Due to the climatic conditions of southern Brazil, fruit set from year to year is very variable and under these conditions, the adoption of thinning during blooming becomes a practice of higher risk for the producer, as it is only possible to assess the thinning need and intensity after the fecundation of flowers. Among chemical thinners available for the apple culture, NAA (naphthalene acetic acid), carbaryl (Sevin $\left.{ }^{\circledR}\right)$, benzyladenine (BA) and ethephon (Ethrel $\left.{ }^{\circledR}\right)$ stand out, and more recently metamitron, a product that inhibits the photosynthetic activity (BASAK, 2011; STERN, 2014; GREENE, 2014). This new mode of action will enable the development and introduction of new technologies for chemical thinning.

The effect of BA on apple tree thinning is proportional to the time of application and concentration used (GREENE et al., 1990). BA is a compound from the group of cytokines acting in cell division, and this has been shown to increase the fruit size (MCLAUGHLIN; GREENE, 1984; GREENE et al., 1992; BYERS; CARBAUGH, 1991; WISMER et al., 1995). According to Greene (2005), BA can increase the fruit size in the absence of thinning by increasing cell division. BA has been regarded as a good thonner due to its low toxicological profile and biological action of cytokinin that is synthesized in plants (YUAN; GREENE, 2000a; 2000b). The combination of BA with carbaryl has been more effective than isolated application, being considered one of the most effective combinations for chemical thinning of apple (BYERS; CARBAUGH, 1991).
In Brazil, the post-bloom application of carbaryl or mixture of carbaryl with NAA and BA has been used for many years for chemical thinning of apple, which can be applied one or more times according to the relationship between productive capacity and blooming intensity. With the marketing and production restriction of carbaryl, new alternatives aimed at post-bloom thinning have been proposed. Many herbicides such as terbacil, bromacil, metribucin and metamitron are photosynthesis inhibitors (LAFER, 2010). Recent studies have demonstrated the effectiveness of metamitron alone or in combination with benzyladenine in the post-bloom thinning of apples (GREENE, 2014; BRUNNER, 2014; FALLAHI et al 2014.).

The aim of this study was to evaluate the response of metamitron application (Goltix $\left.{ }^{\circledR}\right)$ in two concentrations, alone or in combination with benzyladenine in the post-bloom thinning of 'Fuji Suprema', 'MaxiGala' and 'Fred Hough' apple cultivars.

\section{MATERIAL AND METHODS}

The experiments were conducted in an experimental orchard located in the municipality of Caçador, SC, (2704'S, 5052'W, 960 asl). Apple trees Fuji Suprema / M-9, MaxiGala / M-9 and Fred Hough / M-9 cultivars were used (with planting density of 2,500 plants ha ${ }^{-1}$ ) conducted in central leader system and managed in accordance with apple production system recommendations .

The experimental design was a randomized complete block design with five replicates of one plant per plot and six treatments in Fuji Suprema and MaxiGala cultivars and ten treatments and six repetitions in Fred Hough cultivar. Treatments and the application stage are shown in Tables 1 and 2. Maximum and minimum temperature and daily rainfall data during the evaluation period of the efficiency of thinners are presented in Figure 1. Hand thinning adopted the criterion of maintenance two fruits in brindles and one fruit in spur, and in the chemical and control thinning treatments, manual thinning complement was not performed. Commercial products $\mathrm{MaxCel}{ }^{\circledR}(2 \% \mathrm{BA})$ and Goltix ${ }^{\circledR}(48 \%$ metamitron) were used as source of benzyladenine-6 (BA) and metamitron, respectively. Products were applied using a motor knapsack sprayer (20L) with ferrule containing three fan-type D-S nozzles.

Fruit set was obtained from the relationship between number of flower clusters counted during full blooming and number of fruits at 30 days after 
full blooming ([number of fruits / floral clusters] $\mathrm{x} 100)$. The percentage of floral clusters with fruit and number of fruits per inflorescence were estimated by counting the number of fruits on each inflorescence before and 30 days after treatment application, estimated their percentage in the four categories: floral clusters with 1 fruit, 2 fruits, 3 fruits, 4 fruits or more. When the harvest point was reached, fruits were weighed and counted, obtaining production of fruits per plant and number of fruits per plant and estimating the fresh weight of fruits and productivity estimate in $\mathrm{tha}^{-1}$.

The evaluation of the 'russeting' incidence in fruits was carried out using a scale from 0 to 4 where 0 is no disturbance and 4 is the occurrence of the disturbance on the entire fruit surface. Fruit size was evaluated using all harvested fruits of each plot, with fruit classified into three categories (fruits smaller than $55 \mathrm{~mm}$ in diameter, fruits with 56 to $64 \mathrm{~mm}$ in diameter and fruits larger than $65 \mathrm{~mm}$ in diameter), also calculating their percentage. For the 'Fred Hough' cultivar, the flowering return in production cycle subsequent to the application of thinning treatments was assessed, being obtained from the count of the total number of buds and number of flower buds in the marked branch ([number of flower buds / total number of buds] x100), expressed as a percentage.

The statistical analysis of data was performed by analysis of variance, and the comparison of means was made by the Scott Knott test at 5\% error probability in variables that revealed significant by the $F$ test $(p \leq 0.05)$. To carry out the statistical analysis, the Sisvar software, version 5.3 was used (FERREIRA, 2010).

\section{RESULTS AND DISCUSSION}

\section{'Fuji Suprema'}

Metamitron $768 \mathrm{mg} \mathrm{L}^{-1}$ metamitron 384 mg L $\mathrm{L}^{-1}+$ benzyladenine $40 \mathrm{mg} \mathrm{L}^{-1}$ and metamitron $768 \mathrm{mg} \mathrm{L}^{-1}+$ benzyladenine $40 \mathrm{mg} \mathrm{L}^{-1}$ treatments reduced fruit set, the percentage of inflorescences with fruits and the number of fruits per inflorescence when applied to fruit with 5 to $10 \mathrm{~mm}$ in diameter in comparison to the other treatments (Table 3 and 4). Reginato et al. (2014) reported a reduction in fruit set with two applications metamitron, resulting in fewer fruits at harvest. Regarding the percentage of inflorescences with $1,2,3,4$ or more fruits, no significant differences among treatments were observed (Table 4).

Production per plant and estimated yield showed no significant differences among the different treatments and hand thinning (Table 5). The estimated yield $\left(\mathrm{t} \mathrm{ha}^{-1}\right)$ in all treatments is considered adequate, showing the efficiency of metamitron or metamitron plus benzyladenin in the chemical thinning of Fuji Suprema cultivar. A reduction in the number of fruits per plant was observed in the following treatments: metamitron $384 \mathrm{mg} \mathrm{L}^{-1}$, metamitron $768 \mathrm{mg} \mathrm{L}^{-1}$, metamitron $384 \mathrm{mg} \mathrm{L}^{-1}+$ benzyladenine $40 \mathrm{mg}$ $\mathrm{L}^{-1}$ and metamitron $768 \mathrm{mg} \mathrm{L}^{-1}+$ benzyladenine $40 \mathrm{mg} \mathrm{L}^{-1}$ treatments applied to fruits of 5 to 10 $\mathrm{mm}$ in diameter, compared with hand thinning and metamitron $384 \mathrm{mg} \mathrm{L}^{-1}+$ benzyladenine $40 \mathrm{mg} \mathrm{L}^{-1}$ applied to fruits of 15 to $20 \mathrm{~mm}$ in diameter, which shows the thinning action of these treatments when applied at this fruit stage (Table 5). According to Mcartney and Obermiller (2012), the thinning action of metamitron can be observed in fruits of up to 20 $\mathrm{mm}$ diameter. In all chemical thinning treatments, the fresh weight of fruits was higher compared to hand thinning, except for metamitron $384 \mathrm{mg} \mathrm{L}^{-1}+$ benzyladenine $40 \mathrm{mg} \mathrm{L}^{-1}$ applied to fruits of 15 to $20 \mathrm{~mm}$ in diameter, showing an increase in the fresh weight of fruits from $26.2 \%$ to $40.3 \%$, compared with hand thinning (Table 5). Reginato et al. (2014) emphasized the importance of removing excess fruit to increased fresh fruit weight. According to Lafer (2010), increased fruit size during thinning with metamitron is proportional to the reduction in the number of fruits at the initial development stage. The results show that metamitron alone or in admixture with benzyladenine was effective as thinning agent when applied to fruits fo 5 to $10 \mathrm{~mm}$ in diameter, which confirms the results of Brunner (2014), who achieved maximum fruit set reduction in "Fuji" apple trees when metamitron was applied in fruits of 12 $\mathrm{mm}$ in diameter.

\section{'MaxiGala'}

Fruit set was drastically reduced in treatments with metamitron $384 \mathrm{mg} \mathrm{L}^{-1}$, metamitron $768 \mathrm{mg} \mathrm{L}^{-1}$, metamitron $384 \mathrm{mg} \mathrm{L}^{-1}+$ benzyladenine $20 \mathrm{mg} \mathrm{L}^{-1}$ and metamitron $768 \mathrm{mg} \mathrm{L}^{-1}+$ benzyladenine $20 \mathrm{mg}$ $\mathrm{L}^{-1}$ when applied to fruits of 5 to $10 \mathrm{~mm}$ in diameter in comparison to the other treatments. With fruit set reduction, the treatments mentioned above have reduced the percentage of inflorescences with fruits (Table 3).

A reduction in production $\left(\mathrm{kg}\right.$ plant $\left.{ }^{-1}\right)$ and estimated yield $\left(\mathrm{t} \mathrm{ha}^{-1}\right)$ were observed in all treatments compared to the control treatment. Treatments with metamitron $384 \mathrm{mg} \mathrm{L}^{-1}+$ benzyladenine $20 \mathrm{mg} \mathrm{L}^{-1}$ in fruits of 5 to $10 \mathrm{~mm}$ in diameter and fruits of 15 to $20 \mathrm{~mm}$ in diameter, significantly differing from the other treatments with metamitron or metamitron + 
benzyladenine, but only treatment with metamitron $384 \mathrm{mg} \mathrm{L}^{-1}+$ benzyladenine $20 \mathrm{mg} \mathrm{L}^{-1}-15$ to 20 $\mathrm{mm}$ a considered economically appropriate yield was obtained with $46.77 \mathrm{t} \mathrm{ha}^{-1}$, while the other treatments with chemical thinners were from 10.33 t ha ${ }^{-1}$ to $27.52 \mathrm{t} \mathrm{ha}^{-1}$ (Table 6). The results show the strong thinning action of metamitron alone or mixed with benzyladenin in MaxiGala cultivar, since control treatment without thinning showed productivity of $89.6 \mathrm{tha}^{-1}$, which can be considered excessive. According to Lafer (2010), applications of metamitron $350 \mathrm{mg} \mathrm{L}^{-1}$ in fruits with $5-8 \mathrm{~mm}$ in diameter caused excessive thinning within one year, and thinning was not effective the following yearn, and was also not effective when applied to fruits of 12 to $14 \mathrm{~mm}$ in diameter. High metamitron concentrations can cause excessive thinning and it should be considered that high temperatures (29 to $31^{\circ} \mathrm{C}$ ) in the application or up to 4 days after intensified the thinning action to recommended values of 150-300 $\mathrm{mg} \mathrm{L}^{-1}$ (GREENE, 2014 ).

For the number of fruits per plant, response similar to that observed in fruit production per plant was observed, causing a reduction in the number of fruits in all treatments with thinning compared to control treatment (Table 6). The use of metamitron $384 \mathrm{mg} \mathrm{L}^{-1}+$ benzyladenine $20 \mathrm{mg} \mathrm{L}^{-1}$ in fruits of 15 to $20 \mathrm{~mm}$ in diameter reflected in lower intensity thinning compared to treatments applied to fruits of 5 to $10 \mathrm{~mm}$ in diameter, presenting better fruit load adjustment in relation to the plant productive capacity. According to Deckers et al., (2010), the use of metamitron $175 \mathrm{mg} \mathrm{L}^{-1}$ in 'Elstar' apple trees does not cause excessive thinning, but at doses greater than $350 \mathrm{mg} \mathrm{L}^{-1}$, burning symptoms are observed in the side edges of leaves. It is noteworthy that the metamitron concentrations used (384 and $768 \mathrm{mg} \mathrm{L}^{-1}$ ) determined excessive thinning in MaxiGala cultivar when thinning was performed in fruits of 5 to 10 $\mathrm{mm}$ in diameter. According to Basak (2011), under appropriate atmospheric conditions for application of active ingredient, two metamitron applications (350 $\mathrm{mg} \mathrm{L}^{-1}$ ) provided good thinning action in 'Gala Must' apple trees, while in another harvest season in the same cultivar, but with unsuitable weather at flowering, a single application provided good thinning and two applications caused excessive thinning.

The average fresh fruit weight $(\mathrm{g})$ was reduced as a function of productivity, being significantly lower in higher productivity treatments (Table 6). According to Brunner (2014), the average fruit weight is increased according to the thinning effectiveness, and higher average fruit weights were obtained from treatments that reduced production. The reduction in average fresh fruit weight led to a smaller percentage of fruits in larger size class and to a higher percentage of fruits in the smallest size class (Table 7). Although the use of metamitron at concentration of $768 \mathrm{mg} \mathrm{L}^{-1}$ has presented phytotoxicity on leaves, there was no increase in the 'russeting' incidence the various classes of 'MaxiGala' apple trees (Table 8).

\section{'Fred Hough'}

Fruit set, number of fruits per inflorescence after thinning and percentage of fallen fruits significantly differed among treatments, and treatments with metamiron $768 \mathrm{mg} \mathrm{L}^{-1}$ applied on fruits of 5-15 $\mathrm{mm}$ in diameter, benzyladenine 40 mg L ${ }^{-1}+$ metamitron $768 \mathrm{mg} \mathrm{L}^{-1}$ applied on fruits of $5-15 \mathrm{~mm}$ in diameter, benzyladenine $40 \mathrm{mg} \mathrm{L}^{-1}$ + metamitron $384 \mathrm{mg} \mathrm{L}^{-1}$ applied on fruits of 5-15 $\mathrm{mm}$ in diameter and benzyladenine $40 \mathrm{mg} \mathrm{L}^{-1}+$ Ethrel ${ }^{\circledR} 1.5 \mathrm{~L} \mathrm{ha}^{-1}$ applied on fruits of $5-15 \mathrm{~mm}$ in diameter reduced fruit set and the number of fruits per inflorescence after thinning and the average number of fruits per branch as compared to the other treatments (Tables 9 and 10).

In 'Fred Hough' apple trees, treatments with metamitron $768 \mathrm{mg} \mathrm{L}^{-1}$ applied on fruits of 5-15 $\mathrm{mm}$ in diameter and benzyladenine $40 \mathrm{mg} \mathrm{L}^{-1}+$ metamitron $384 \mathrm{mg} \mathrm{L}^{-1}$ applied on fruits of 5-15 mm in diameter reduced the percentage of inflorescences with 3 fruits (Table 11). However, treatments with benzyladenine $40 \mathrm{mg} \mathrm{L}^{-1}+$ metamitron $768 \mathrm{mg} \mathrm{L}$ ${ }^{-1}$ and benzyladenine $40 \mathrm{mg} \mathrm{L}^{-1}+$ Ethrel ${ }^{\circledR} 1.5 \mathrm{~L}$ $\mathrm{ha}^{-1}$, when applied to fruits of 5-15 $\mathrm{mm}$ in diameter reduced the proportion of inflorescences with 4 or more fruits (Table 11). To obtain fruits of greater size, the maintenance of more than 3 fruits per inflorescence after thinning is not desirable. Thus, thinning treatments that reduce the proportion of inflorescences with 3 or more fruits seem to be efficient. For 'Fred Hough' cultivar, benzyladenine 40 $\mathrm{mg} \mathrm{L}^{-1}$ and metamitron $384 \mathrm{~m} \mathrm{~L} \mathrm{~L}^{-1}$ applied in isolation in fruits of 5-15 $\mathrm{mm}$ in diameter, and the combined application of these substances in fruits of 15-20 $\mathrm{mm}$, had no effect on the reduction of the proportion of floral cluster fruit with 3 to 4 fruits, indicating low thinning efficiency compared to treatment with the combination of active ingredients (Tabela11). According to Greene (2014), the chemical mixture of thinning agents with different mechanisms of action may enhance the thinning effect, being particularly interesting in apple cultivars with high fruit set such as 'Fred Hough'. Thus, as observed in this study in "Fuji Supreme" and "Maxi Gala" apple cultivars, 
the chemical thinning efficiency, even using more than one active ingredient, has limited efficiency in fruits with diameter exceeding $15 \mathrm{~mm}$, as reported by Greene (2002) and Robinson; Lakso (2011).

Treatments that reduced the proportion of inflorescences with 3 or more fruits showed better response for production per plant and estimated yield per hectare. Hand thinning, metamitron 384 $\mathrm{mg} \mathrm{L}{ }^{-1}$, benzyladenine $40 \mathrm{mg} \mathrm{L}^{-1}+$ Ethrel $^{\circledR} 1.5 \mathrm{~L}$ ha $^{-1}$, benzyladenine $40 \mathrm{mg} \mathrm{L}^{-1}+$ metamitron $384 \mathrm{mg}$ $\mathrm{L}^{-1}$, benzyladenine $40 \mathrm{mg} \mathrm{L}^{-1}+$ metamitron $768 \mathrm{mg}$ $\mathrm{L}^{-1}$ treatments, when applied to fruit of 5-15 mm in diameter significantly reduced plant production and estimated yield in comparison to the other treatments, while still maintaining high productivity per hectare, at levels consistent with the plant production capacity (Table 12).

In treatment without thinning, estimated yield of $115.94 \mathrm{t} \mathrm{ha}^{-1}$ was obtained, higher than that of hand thinning of $74.42 \mathrm{t} \mathrm{ha}^{-1}$, and some of the treatments remained close to hand thinning. The production return in the following year without the application of chemical thinners showed alternate bearing in higher productivity treatments or with applications in fruits of $15-20 \mathrm{~mm}$ in diameter (Table 13). This result corroborates those obtained by REGINATO (2014), which indicates the need for adequate fruit load adjustment in order to obtain return flowering rates sufficient to ensure production in the production cycle subsequent to the thinning application. Information regarding the effectiveness of metamitron at higher concentrations and higher fruit size is still limited. However, in the study by Brunner (2014), evaluating metamitron at concentrations up to $900 \mathrm{mg} \mathrm{L}^{-1}$, it was found that the use of this thinner at fruit phase of $8 \mathrm{~mm}$ in diameter in 'Golden Delicious' cultivar determined decrease in production per plant proportionally to the increase in concentration, as well as an increase in fruit weight.

The average fresh fruit weight was significantly higher, and in hand thinning treatment, metamitron $768 \mathrm{mg} \mathrm{L}^{-1}$ applied to fruits of 5-15 mm in diameter, benzyladenine $40 \mathrm{mg} \mathrm{L}^{-1}+$ metamitron $384 \mathrm{mg} \mathrm{L}^{-1}$ applied to fruits of 5-15 mm in diameter, benzyladenine $40 \mathrm{mg} \mathrm{L}^{-1}+$ metamitron $768 \mathrm{mg} \mathrm{L}^{-1}$ applied to fruit of $5-15 \mathrm{~mm}$ in diameter. The results show high influence related to the application stage, and applications to fruits of $15-20 \mathrm{~mm}$ in diameter showed no increase in fresh fruit weight. The distribution of fruits into size classes showed significant differences, and treatments with higher productivity showed reduced number of higher size fruits and increased number of lower size fruits (Table 14). Stern (2014) and gabardo (2015) observed a better distribution of largest fruits with increasing metamitron concentration applied at thinning. BRUNNER (2014) observed a large variability of the effect of metamitron among cultivars, concentration and application time. The higher allocation of fruits in higher size class was observed in hand thinning, with $58.22 \%$ in size over $65 \mathrm{~mm}$ in diameter, which did not significantly differ from treatment with benzyladenine $40 \mathrm{mg} \mathrm{L}^{-1}+$ metamitron $384 \mathrm{mg} \mathrm{L}^{-1}$ applied to fruits of $5-15 \mathrm{~mm}$ in diameter and $55.33 \%$ higher than the control treatment. According to Silva (2014), chemical thinning in 'Fuji' apple trees led to a slightly higher size of fruits, compared to control (untreated), although without statistically significant differences. All types and chemical combinations of thinning agents increased the floral differentiation in the following year, but only some combinations showed significant statistical differences. 
TABLE 1 - Tratamentos used: technical name, concentration and application stage, 'Fuji Suprema' and 'MaxiGala'cultivars. Caçador-SC, 2015.

\begin{tabular}{|c|c|}
\hline Treatment & Fruit sizes (mm) - Application date \\
\hline Hand thinning & $15-20 \mathrm{~mm}-10 / 30 / 2012$ \\
\hline Metamitron $384 \mathrm{mg} \mathrm{L}^{-1}$ & $5-10 \mathrm{~mm}-10 / 17 / 2012$ \\
\hline Metamitron $768 \mathrm{mg} \mathrm{L}^{-1}$ & $5-10 \mathrm{~mm}-10 / 17 / 2012$ \\
\hline Metamitron $384 \mathrm{mg} \mathrm{L}^{-1}+$ Benzyladenine $40 \mathrm{mg} \mathrm{L}^{-1 *}$ & $5-10 \mathrm{~mm}-10 / 17 / 2012$ \\
\hline Metamitron $768 \mathrm{mg} \mathrm{L}^{-1}+$ Benzyladenine $40 \mathrm{mg} \mathrm{L}^{-1}$ & $5-10 \mathrm{~mm}-10 / 17 / 2012$ \\
\hline Metamitron $384 \mathrm{mg} \mathrm{L}^{-1}+$ Benzyladenine $40 \mathrm{mg} \mathrm{L}^{-1}$ & $15-20 \mathrm{~mm}-10 / 29 / 2012$ \\
\hline
\end{tabular}

TABLE 2- Treatments used: active ingredient, concentration and application date, Fred Hough cultivar. Caçador-SC, 2015.

\begin{tabular}{|c|c|}
\hline Treatment & Fruit sizes (mm) - Application date \\
\hline Control - no thinning & - \\
\hline Benzyladenine $40 \mathrm{mg} \mathrm{L}^{-1}$ & $5-10 \mathrm{~mm}-10 / 16 / 2012$ \\
\hline Metamitron $384 \mathrm{mg} \mathrm{L}^{-1}$ & $5-10 \mathrm{~mm}-10 / 16 / 2012$ \\
\hline Metamitron $768 \mathrm{mg} \mathrm{L}^{-1}$ & $5-10 \mathrm{~mm}-10 / 16 / 2012$ \\
\hline Benzyladenine $40 \mathrm{mg} \mathrm{L}^{-1}+$ Ethrel $^{\circledR} 1,5 \mathrm{~L} \mathrm{ha}^{-1}$ & $15 \mathrm{~mm}-10 / 16 / 2012$ \\
\hline Benzyladenine $40 \mathrm{mg} \mathrm{L}^{-1}+$ Metamitron $384 \mathrm{mg} \mathrm{L}^{-1}$ & $5-10 \mathrm{~mm}-10 / 16 / 2012$ \\
\hline Benzyladenine $40 \mathrm{mg} \mathrm{L}^{-1}+$ Metamitron $768 \mathrm{mg} \mathrm{L}^{-1}$ & $5-10 \mathrm{~mm}-10 / 16 / 2012$ \\
\hline Benzyladenine $40 \mathrm{mg} \mathrm{L}^{-1}+$ Metamitron $384 \mathrm{mg} \mathrm{L}^{-1}$ & $15-20 \mathrm{~mm}-10 / 29 / 2012$ \\
\hline Metamitron $384 \mathrm{mg} \mathrm{L}^{-1}$ & $15-20 \mathrm{~mm}-10 / 29 / 2011$ \\
\hline Hand thinning & $20-25 \mathrm{~mm}-10 / 30 / 2012$ \\
\hline
\end{tabular}

TABLE 3- Fruit set and percentage of inflorescences with fruits in 'Fuji Suprema' and 'MaxiGala' apple cultivars due to chemical thinning treatments. Caçador-SC, 2015.

\begin{tabular}{|c|c|c|c|c|}
\hline \multirow{3}{*}{ Treatments } & \multicolumn{2}{|c|}{ 'Fuji Suprema' } & \multicolumn{2}{|c|}{ 'MaxiGala' } \\
\hline & Fruit set & $\begin{array}{c}\text { Inflorescences } \\
\text { with fruit }\end{array}$ & Fruit set & $\begin{array}{l}\text { Inflorescences } \\
\text { with fruit }\end{array}$ \\
\hline & & ------------------( & \%)----- & ----- \\
\hline Control - no thinning & $257.7 \mathrm{a}$ & $88.3 \mathrm{a}$ & $132.1 \mathrm{a}$ & $61.4 \mathrm{a}$ \\
\hline Metamitron $384 \mathrm{mg} \mathrm{L}^{-1}(5-10 \mathrm{~mm})^{*}$ & $290.6 \mathrm{a}$ & $90.0 \mathrm{a}$ & $8.9 \mathrm{~b}$ & $8.9 \mathrm{~b}$ \\
\hline Metamitron $768 \mathrm{mg} \mathrm{L}^{-1}(5-10 \mathrm{~mm})$ & $143.3 \mathrm{~b}$ & $64.7 \mathrm{~b}$ & $5.3 \mathrm{~b}$ & $4.7 \mathrm{~b}$ \\
\hline $\begin{array}{l}\text { Metamitron } 384 \mathrm{mg} \mathrm{L}^{-1}+\text { Benzyladenine } 40 \mathrm{mg} \mathrm{L}^{-1} \\
(5-10 \mathrm{~mm})\end{array}$ & $159.2 \mathrm{~b}$ & $76.7 \mathrm{~b}$ & $11.9 \mathrm{~b}$ & $9.2 \mathrm{~b}$ \\
\hline $\begin{array}{l}\text { Metamitron } 768 \mathrm{mg} \mathrm{L}^{-1}+\text { Benzyladenine } 40 \mathrm{mg} \mathrm{L}^{-1} \\
(5-10 \mathrm{~mm})\end{array}$ & $150.6 \mathrm{~b}$ & $66.7 \mathrm{~b}$ & $1.6 \mathrm{~b}$ & $1.6 \mathrm{~b}$ \\
\hline $\begin{array}{l}\text { Metamitron } 384 \mathrm{mg} \mathrm{L}^{-1}+\text { Benzyladenine } 40 \mathrm{mg} \mathrm{L}^{-1} \\
(15-20 \mathrm{~mm})\end{array}$ & 289.9 a & $92.5 \mathrm{a}$ & $102.9 \mathrm{a}$ & $45.7 \mathrm{a}$ \\
\hline $\mathrm{VC} \%$ & 22.8 & 19.6 & 49.6 & 31.9 \\
\hline
\end{tabular}

Means followed by the same letter do not differ by the Scott Knott, test at $5 \%$ probability * fruit diameter at the time of application. 
TABLE 4 - Percentage of inflorescences with 1, 2, 3, 4 or more fruits and number of fruits per inflorescence in 'Fuji Suprema' apple cultivar due to different chemical thinning treatments. Caçador-SC, 2015.

\begin{tabular}{|c|c|c|c|c|c|}
\hline \multirow{3}{*}{ Treatments } & \multicolumn{4}{|c|}{ Inflorescences $(\%)$} & \multirow[b]{2}{*}{$\mathbf{C}$} \\
\hline & 1 & 2 & 3 & 4 & \\
\hline & \multicolumn{4}{|c|}{------------fruits----------- } & \\
\hline Control (no thinning) & $13.6^{\mathrm{ns}}$ & $30.5^{\mathrm{ns}}$ & $25.4^{\mathrm{ns}}$ & $30.5^{\mathrm{ns}}$ & $2.9 \mathrm{a}$ \\
\hline Metamitron $384 \mathrm{mg} \mathrm{L}^{-1}(5-10 \mathrm{~mm})^{*}$ & 15.7 & 20.0 & 17.9 & 46.4 & $3.2 \mathrm{a}$ \\
\hline Metamitron $768 \mathrm{mg} \mathrm{L}^{-1}(5-10 \mathrm{~mm})$ & 33.0 & 30.8 & 19.7 & 16.5 & $2.2 \mathrm{~b}$ \\
\hline $\begin{array}{l}\text { Metamitron } 384 \mathrm{mg} \mathrm{L}^{-1}+\text { Benzyladenine } 40 \mathrm{mg} \mathrm{L}^{-1} \\
(5-10 \mathrm{~mm})\end{array}$ & 27.7 & 45.4 & 19.4 & 7.5 & $2.1 \mathrm{~b}$ \\
\hline $\begin{array}{l}\text { Metamitron } 768 \mathrm{mg} \mathrm{L}^{-1}+\text { Benzyladenine } 40 \mathrm{mg} \mathrm{L}^{-1} \\
(5-10 \mathrm{~mm})\end{array}$ & 25.7 & 40.6 & 17.5 & 16.2 & $2.3 \mathrm{~b}$ \\
\hline $\begin{array}{l}\text { Metamitron } 384 \mathrm{mg} \mathrm{L}^{-1}+\text { Benzyladenine } 40 \mathrm{mg} \mathrm{L}^{-1} \\
(15-20 \mathrm{~mm})\end{array}$ & 13.6 & 23.3 & 21.6 & 41.5 & $3.1 \mathrm{a}$ \\
\hline VC\% & 51.8 & 32.7 & 50.6 & 65.5 & 23.7 \\
\hline
\end{tabular}

Means followed by the same letter do not differ by the Scott Knott, test at $5 \%$ probability. ns: not significant. * Fruit diameter at the time of application.

TABLE 5 - Production and average number of fruits per plant, average fresh fruit weight, estimated yield in 'Fuji Suprema' apple cultivar for different chemical thinning treatments. Caçador-SC, 2015.

\begin{tabular}{|c|c|c|c|c|}
\hline \multirow[t]{2}{*}{ Treatments } & $\begin{array}{l}\text { Production } \\
\text { per plant }\end{array}$ & $\begin{array}{c}\text { Number of } \\
\text { fruits per } \\
\text { plant }\end{array}$ & $\begin{array}{l}\text { Average fresh } \\
\text { fruit weight }\end{array}$ & $\begin{array}{l}\text { Estimated } \\
\text { yield }\end{array}$ \\
\hline & kg & fruits & (g) & t.hat \\
\hline Control (no thinning) & $21.3^{\mathrm{ns}}$ & $247.4 \mathrm{a}$ & $86.4 \mathrm{~b}$ & $53.1 \mathrm{~ns}$ \\
\hline Metamitron $384 \mathrm{mg} \mathrm{L}^{-1}(5-10 \mathrm{~mm}) *$ & 16.6 & $143.2 \mathrm{~b}$ & $116.2 \mathrm{a}$ & 41.4 \\
\hline Metamitron $768 \mathrm{mg} \mathrm{L}^{-1}(5-10 \mathrm{~mm})$ & 16.6 & $139.8 \mathrm{~b}$ & $117.9 \mathrm{a}$ & 41.5 \\
\hline $\begin{array}{l}\text { Metamitron } 384 \mathrm{mg} \mathrm{L}^{-1}+\text { Benzyladenine } 40 \mathrm{mg} \mathrm{L}^{-1} \\
(5-10 \mathrm{~mm})\end{array}$ & 16.8 & $153.6 \mathrm{~b}$ & $109.1 \mathrm{a}$ & 42.1 \\
\hline $\begin{array}{l}\text { Metamitron } 768 \mathrm{mg} \mathrm{L}^{-1}+\text { Benzyladenine } 40 \mathrm{mg} \mathrm{L}^{-1} \\
(5-10 \mathrm{~mm})\end{array}$ & 17.2 & $137.2 \mathrm{~b}$ & $121.3 \mathrm{a}$ & 43.0 \\
\hline $\begin{array}{l}\text { Metamitron } 384 \mathrm{mg} \mathrm{L}^{-1}+\text { Benzyladenine } 40 \mathrm{mg} \mathrm{L}^{-1} \\
(15-20 \mathrm{~mm})\end{array}$ & 19.3 & $198.2 \mathrm{a}$ & $97.4 \mathrm{~b}$ & 48.3 \\
\hline VC $(\%)$ & 29.6 & 13.7 & 11.4 & 29.6 \\
\hline
\end{tabular}

Means followed by the same letter do not differ by the Scott Knott, test at 5\% probability. ns: not significant. * Fruit diameter at the time of application. 
TABLE 6 - Production per plant, number of fruits per plant, average fresh fruit weight, estimated yield $\left(\mathrm{t} \mathrm{ha}^{-1}\right)$ in 'MaxiGala' apple cultivar for different chemical thinning treatments. Caçador-SC, 2015.

\begin{tabular}{|c|c|c|c|c|}
\hline \multirow[t]{2}{*}{ Treatments } & $\begin{array}{l}\text { Production } \\
\text { per plant }\end{array}$ & $\begin{array}{l}\text { Number } \\
\text { of fruits } \\
\text { per plant }\end{array}$ & $\begin{array}{l}\text { Average fresh } \\
\text { fruit weight }\end{array}$ & $\begin{array}{c}\text { Estimated } \\
\text { yield }\end{array}$ \\
\hline & kg & fruits & $\mathbf{g}$ & t.ha-1 \\
\hline Control (no thinning) & $35.8 \mathrm{a}$ & $423.2 \mathrm{a}$ & $83.7 \mathrm{c}$ & $89.6 \mathrm{a}$ \\
\hline Metamitron $384 \mathrm{mg} \mathrm{L}^{-1}(5-10 \mathrm{~mm}) *$ & $4.1 \mathrm{c}$ & $30.2 \mathrm{~d}$ & $137.8 \mathrm{a}$ & $10,3 \mathrm{c}$ \\
\hline Metamitron $768 \mathrm{mg} \mathrm{L}^{-1}(5-10 \mathrm{~mm})$ & $4.8 \mathrm{c}$ & $41.4 \mathrm{~d}$ & $113.9 \mathrm{~b}$ & $12,0 \mathrm{c}$ \\
\hline $\begin{array}{l}\text { Metamitron } 384 \mathrm{mg} \mathrm{L}^{-1}+\text { Benzyladenine } 20 \mathrm{~m} \mathrm{~L}^{-1} \\
(5-10 \mathrm{~mm})\end{array}$ & $11.0 \mathrm{~b}$ & $82.6 \mathrm{c}$ & $134.4 \mathrm{a}$ & $27.5 b$ \\
\hline $\begin{array}{l}\text { Metamitron } 768 \mathrm{mg} \mathrm{L}^{-1}+\text { Benzyladenine } 20 \mathrm{mg} \mathrm{L}^{-1} \\
(5-10 \mathrm{~mm})\end{array}$ & $4.7 \mathrm{c}$ & $37.2 \mathrm{~d}$ & $118.1 \mathrm{~b}$ & $11.7 \mathrm{c}$ \\
\hline $\begin{array}{l}\text { Metamitron } 384 \mathrm{mg} \mathrm{L}^{-1}+\text { Benzyladenine } 20 \mathrm{mg} \mathrm{L}^{-1} \\
(15-20 \mathrm{~mm})\end{array}$ & $18.7 \mathrm{~b}$ & $193.8 \mathrm{~b}$ & $99.8 \mathrm{c}$ & $46.8 \mathrm{~b}$ \\
\hline $\mathrm{VC}(\%)$ & 47.7 & 22.4 & 10.7 & 47.7 \\
\hline
\end{tabular}

Means followed by the same letter do not differ by the Scott Knott test at 5\% probability. ${ }^{*}$ Fruit diameter at the time of application.

TABLE 7-Distribution of fruits into size classes (135, 165 and 180) of 'MaxiGala' fruits with different chemical thinning treatments. Caçador, SC, 2015.

\begin{tabular}{|c|c|c|c|}
\hline \multirow[b]{2}{*}{ Treatments } & \multicolumn{3}{|c|}{$\begin{array}{l}\text { Percentage of fruits according } \\
\text { to fruit size }\end{array}$} \\
\hline & $\begin{array}{l}\geq 65 \mathrm{~mm} \text { in } \\
\text { diameter }\end{array}$ & $\begin{array}{c}56 \mathrm{~mm} \\
\text { to } 64 \mathrm{~mm} \\
\text { in diameter } \\
\end{array}$ & $\begin{array}{l}\leq 55 \mathrm{~mm} \text { in } \\
\text { diameter }\end{array}$ \\
\hline Control (no thinning) & $0.1 \mathrm{c}$ & $43.4^{\mathrm{ns}}$ & $56.4 \mathrm{a}$ \\
\hline Metamitron $384 \mathrm{mg} \mathrm{L}^{-1}(5-10 \mathrm{~mm})^{*}$ & $36.4 \mathrm{a}$ & 50.6 & $12.9 \mathrm{~b}$ \\
\hline Metamitron $768 \mathrm{mg} \mathrm{L}^{-1}(5-10 \mathrm{~mm})$ & $16.7 \mathrm{a}$ & 53.2 & $30.1 \mathrm{~b}$ \\
\hline Metamitron $384 \mathrm{mg} \mathrm{L}^{-1}+$ Benzyladenine $20 \mathrm{mg} \mathrm{L}^{-1}(5-10 \mathrm{~mm})$ & $25.3 \mathrm{a}$ & 61.5 & $13.2 \mathrm{~b}$ \\
\hline Metamitron $768 \mathrm{mg} \mathrm{L}^{-1}+$ Benzyladenine $20 \mathrm{mg} \mathrm{L}^{-1}(5-10 \mathrm{~mm})$ & $24.7 \mathrm{a}$ & 50.3 & $25.1 \mathrm{~b}$ \\
\hline Metamitron $384 \mathrm{mg} \mathrm{L}^{-1}+$ Benzyladenine $20 \mathrm{mg} \mathrm{L}^{-1}(15-20 \mathrm{~mm})$ & $4.2 \mathrm{~b}$ & 60.7 & $35.0 \mathrm{a}$ \\
\hline $\mathrm{VC}(\%)$ & 28.2 & 26.2 & 44.6 \\
\hline
\end{tabular}

Means followed by the same letter do not differ by the Scott Knott test at $5 \%$ probability. ns: not significant. * Fruit diameter at the time of application. 
TABLE 8 - Distribution of MaxiGala' fruits at different levels of 'russeting' incidence (0, 1, 2, 3 and 4) in different chemical thinning treatment. Caçador-SC, 2015.

\begin{tabular}{|c|c|c|c|c|c|}
\hline \multirow{2}{*}{ Treatments } & \multicolumn{5}{|c|}{ Russeting level (\%)* } \\
\hline & $\mathbf{0}$ & 1 & 2 & 3 & 4 \\
\hline Control (no thinning) & $9.0 \mathrm{~ns}$ & $27.0 \mathrm{~ns}$ & $50.1 \mathrm{~ns}$ & $12.6 \mathrm{~ns}$ & $1.2 \mathrm{~ns}$ \\
\hline Metamitron $384 \mathrm{mg} \mathrm{L}^{-1}(5-10 \mathrm{~mm})^{*}$ & 8.1 & 25.7 & 36.3 & 27.2 & 2.7 \\
\hline Metamitron $768 \mathrm{mg} \mathrm{L}^{-1}(5-10 \mathrm{~mm})$ & 14.9 & 32.6 & 35.0 & 13.9 & 3.5 \\
\hline Metamitron $384 \mathrm{mg} \mathrm{L}^{-1}+$ Benzyladenine $20 \mathrm{mg} \mathrm{L}^{-1}(5-10 \mathrm{~mm})$ & 8.7 & 22.6 & 42.3 & 23.6 & 2.8 \\
\hline Metamitron $768 \mathrm{mg} \mathrm{L}^{-1}+$ Benzyladenine $20 \mathrm{mg} \mathrm{L}^{-1}(5-10 \mathrm{~mm})$ & 3.5 & 16.2 & 36.9 & 37.9 & 5.5 \\
\hline Metamitron $384 \mathrm{mg} \mathrm{L}^{-1}+$ Benzyladenine $20 \mathrm{mg} \mathrm{L}^{-1}(15-20 \mathrm{~mm})$ & 7.3 & 29.7 & 41.3 & 18.7 & 3.0 \\
\hline $\mathrm{VC}(\%)$ & 49.5 & 31.6 & 15.0 & 32.8 & 68.7 \\
\hline
\end{tabular}

* 'Russeting' scale - 0 indicates no disturbance and 4 indicates occurrence of disturbance on the entire fruit surface. Means followed by the same letter do not differ by the Scott Knott test at 5\% probability. ns: not significant. * Fruit diameter at the time of application.

TABLE 9 - Fruit set after thinning and number of fruits per inflorescence before and after thinning in 'Fred Hough' cultivar for different chemical thinning treatments. Caçador-SC, 2015.

\begin{tabular}{|c|c|c|c|}
\hline \multirow{2}{*}{ Treatments } & Fruit set $(\%)$ & \multicolumn{2}{|c|}{$\begin{array}{c}\text { Average number of fruits } \\
\text { per inflorescence }\end{array}$} \\
\hline & \multicolumn{3}{|c|}{ After thinning Before thinning After thinning } \\
\hline Control (no thinning) & $247.3 \mathrm{a}$ & $2.9^{\mathrm{ns}}$ & $2.6 \mathrm{a}$ \\
\hline Benzyladenine $40 \mathrm{mg} \mathrm{L}^{-1}(5-15 \mathrm{~mm})^{*}$ & $228.7 \mathrm{a}$ & 3.0 & $2.6 \mathrm{a}$ \\
\hline Metamitron $384 \mathrm{mg} \mathrm{L}^{-1}(5-15 \mathrm{~mm})$ & $229.7 \mathrm{a}$ & 3.2 & $2.6 \mathrm{a}$ \\
\hline Metamitron $768 \mathrm{mg} \mathrm{L}^{-1}(5-15 \mathrm{~mm})$ & $79.6 \mathrm{~b}$ & 2.8 & $1.7 \mathrm{~b}$ \\
\hline Benzyladenine $40 \mathrm{mg} \mathrm{L}^{-1}+$ Ethrel $^{\circledR} 1,5 \mathrm{~L} / \mathrm{ha}(5-15 \mathrm{~mm})$ & $133.1 \mathrm{~b}$ & 2.9 & $2.1 \mathrm{~b}$ \\
\hline $\begin{array}{l}\text { Benzyladenine } 40 \mathrm{mg} \mathrm{L}^{-1}+\text { metamitron } 384 \mathrm{mg} \mathrm{L}^{-1} \\
(5-15 \mathrm{~mm})\end{array}$ & $110.1 \mathrm{~b}$ & 2.9 & $1.9 \mathrm{~b}$ \\
\hline $\begin{array}{l}\text { Benzyladenine } 40 \mathrm{mg} \mathrm{L}^{-1}+\text { metamitron } 768 \mathrm{mg} \mathrm{L}^{-1} \\
(5-15 \mathrm{~mm})\end{array}$ & $67.3 \mathrm{~b}$ & 3.1 & $2.3 \mathrm{~b}$ \\
\hline $\begin{array}{l}\text { Benzyladenine } 40 \mathrm{mg} \mathrm{L}^{-1}+\text { metamitron } 384 \mathrm{mg} \mathrm{L}^{-1} \\
(15-20 \mathrm{~mm})\end{array}$ & $247.1 \mathrm{a}$ & 3.1 & $2.8 \mathrm{a}$ \\
\hline Metamitron $384 \mathrm{mg} \mathrm{L}^{-1}(15-20 \mathrm{~mm})$ & $245.5 \mathrm{a}$ & 2.9 & $2.7 \mathrm{a}$ \\
\hline $\mathrm{VC} \%$ & 25.7 & 12.3 & 21.6 \\
\hline
\end{tabular}

Means followed by the same letter do not differ by the Scott Knott test at 5\% probability. ns: not significant. * Fruit diameter at the time of application. 
TABLE 10 - Number of fruit before and after thinning and percentage of fallen fruit in 'Fred Hough' cultivar with different chemical thinning treatments. Caçador-SC, 2015.

\begin{tabular}{|c|c|c|c|}
\hline \multirow{2}{*}{ Treatments } & \multicolumn{2}{|c|}{ Number of fruits } & \multirow{2}{*}{ Fallen fruits $(\%$} \\
\hline & Before thinning & After thinning & \\
\hline Control (no thinning) & $43.8 \mathrm{~ns}$ & $36.5 \mathrm{a}$ & $14.7 \mathrm{~b}$ \\
\hline Benzyladenine $40 \mathrm{mg} \mathrm{L}^{-1}(5-15 \mathrm{~mm}) *$ & 44.2 & $34.5 \mathrm{a}$ & $22.9 \mathrm{~b}$ \\
\hline Metamitron $384 \mathrm{mg} \mathrm{L}^{-1}(5-15 \mathrm{~mm})$ & 39.2 & $26.5 \mathrm{a}$ & $30.2 \mathrm{~b}$ \\
\hline Metamitron $768 \mathrm{mg} \mathrm{L}^{-1}(5-15 \mathrm{~mm})$ & 46.7 & $14.3 \mathrm{~b}$ & $72.6 \mathrm{a}$ \\
\hline $\begin{array}{l}\text { Benzyladenine } 40 \mathrm{mg} \mathrm{L}^{-1}+\text { Ethrel }^{\circledR} 1,5 \mathrm{~L} / \mathrm{ha} \\
(5-15 \mathrm{~mm})\end{array}$ & 51.3 & $23.3 \mathrm{~b}$ & $53.6 \mathrm{a}$ \\
\hline $\begin{array}{l}\text { Benzyladenine } 40 \mathrm{mg} \mathrm{L}^{-1}+\text { metamitron } 384 \mathrm{mg} \mathrm{L}^{-1} \\
(5-15 \mathrm{~mm})\end{array}$ & 45.2 & $16.3 \mathrm{~b}$ & $63.5 \mathrm{a}$ \\
\hline $\begin{array}{l}\text { Benzyladenine } 40 \mathrm{mg} \mathrm{L}^{-1}+\text { metamitron } 768 \mathrm{mg} \mathrm{L}^{-1} \\
(5-15 \mathrm{~mm})\end{array}$ & 52.3 & $11.3 \mathrm{~b}$ & $78.8 \mathrm{a}$ \\
\hline $\begin{array}{l}\text { Benzyladenine } 40 \mathrm{mg} \mathrm{L}^{-1}+\text { metamitron } 384 \mathrm{mg} \mathrm{L}^{-1} \\
(15-20 \mathrm{~mm})\end{array}$ & 49.3 & $40.2 \mathrm{a}$ & $21.0 \mathrm{~b}$ \\
\hline Metamitron $384 \mathrm{mg} \mathrm{L}^{-1}(15-20 \mathrm{~mm})$ & 56.5 & $48.5 \mathrm{a}$ & $15.4 \mathrm{~b}$ \\
\hline $\mathrm{VC} \%$ & 19.4 & 26.7 & 28.4 \\
\hline
\end{tabular}

Means followed by the same letter do not differ by the Scott Knott test at $5 \%$ probability. ns: not significant. * Fruit diameter at the time of application.

TABLE 11- Percentage of inflorescences with 1, 2, 3 and 4 or more fruits after thinning in 'Fred Hough' cultivar with different chemical thinning treatments. Caçador-SC, 2015.

\begin{tabular}{|c|c|c|c|c|}
\hline \multirow{3}{*}{ Treatments } & \multicolumn{4}{|c|}{ Floral clusters with $(\%)$} \\
\hline & 1 & 2 & 3 & 4 \\
\hline & \multicolumn{4}{|c|}{-----------fruits------------ } \\
\hline Control (no thinning) & $22.2 \mathrm{~ns}$ & $27.0 \mathrm{~ns}$ & $19.5 \mathrm{a}$ & $31.3 \mathrm{a}$ \\
\hline Benzyladenine $40 \mathrm{mg} \mathrm{L}^{-1}(5-15 \mathrm{~mm}) *$ & 17.4 & 31.3 & $22.4 \mathrm{a}$ & $28.9 \mathrm{a}$ \\
\hline Metamitron $384 \mathrm{mg} \mathrm{L}^{-1}(5-15 \mathrm{~mm})$ & 18.5 & 28.3 & $26.4 \mathrm{a}$ & $26.8 \mathrm{a}$ \\
\hline Metamitron $768 \mathrm{mg} \mathrm{L}^{-1}(5-15 \mathrm{~mm})$ & 47.6 & 36.5 & $9.6 \mathrm{~b}$ & $6.3 \mathrm{~b}$ \\
\hline Benzyladenine $40 \mathrm{mg} \mathrm{L}^{-1}+$ Ethre $^{\circledR} 1,5 \mathrm{~L} / \mathrm{ha}(5-15 \mathrm{~mm})$ & 31.8 & 34.4 & $25.7 \mathrm{a}$ & $8.1 \mathrm{~b}$ \\
\hline Benzyladenine $40 \mathrm{mg} \mathrm{L}^{-1}+$ metamitron $384 \mathrm{mg} \mathrm{L}^{-1}(5-15 \mathrm{~mm})$ & 42.9 & 34.0 & $8.9 \mathrm{~b}$ & $14.2 \mathrm{~b}$ \\
\hline Benzyladenine $40 \mathrm{mg} \mathrm{L}^{-1}+$ metamitron $768 \mathrm{mg} \mathrm{L}^{-1}(5-15 \mathrm{~mm})$ & 34.7 & 22.2 & $25.0 \mathrm{a}$ & $18.1 \mathrm{~b}$ \\
\hline Benzyladenine $40 \mathrm{mg} \mathrm{L}^{-1}+$ metamitron $384 \mathrm{mg} \mathrm{L}^{-1}(15-20 \mathrm{~mm})$ & 12.9 & 21.4 & $33.8 \mathrm{a}$ & $31.9 \mathrm{a}$ \\
\hline Metamitron $384 \mathrm{mg} \mathrm{L}^{-1}(15-20 \mathrm{~mm})$ & 17.1 & 27.6 & $25.1 \mathrm{a}$ & $30.2 \mathrm{a}$ \\
\hline $\mathrm{VC} \%$ & 25.3 & 53.8 & 22.6 & 48.2 \\
\hline
\end{tabular}

Means followed by the same letter do not differ by the Scott Knott test at 5\% probability. ns: not significant. * Fruit diameter at the time of application. 
TABLE 12 - Production per plant, number of fruits per plant, average fresh fruit weight, estimated yield $\left(\mathrm{t} \mathrm{ha}^{-1}\right)$ in 'Fred Hough' cultivar with different chemical thinning treatments. Caçador-SC, 2015.

\begin{tabular}{|c|c|c|c|}
\hline Treatments & $\begin{array}{c}\text { Production of } \\
\text { fruits per plant } \\
\text { kg }\end{array}$ & $\begin{array}{l}\text { Number of } \\
\text { fruits per } \\
\text { plant }\end{array}$ & $\begin{array}{c}\text { Average fresh } \\
\text { fruit weight } \\
\text { g }\end{array}$ \\
\hline Control (no thinning) & $46.4 \mathrm{a}$ & $600.3 \mathrm{a}$ & $77.1 \mathrm{c}$ \\
\hline Benzyladenine $40 \mathrm{mg} \mathrm{L}^{-1}(5-15 \mathrm{~mm})^{*}$ & $34.4 \mathrm{a}$ & $419.8 \mathrm{a}$ & $81.9 \mathrm{c}$ \\
\hline Metamitron $384 \mathrm{mg} \mathrm{L}^{-1}(5-15 \mathrm{~mm})$ & $30.8 \mathrm{~b}$ & $313.5 \mathrm{~b}$ & $97.5 \mathrm{~b}$ \\
\hline Metamitron $768 \mathrm{mg} \mathrm{L}^{-1}(5-15 \mathrm{~mm})$ & $34.2 \mathrm{a}$ & $302.7 \mathrm{~b}$ & $116.8 \mathrm{a}$ \\
\hline Benzyladenine $40 \mathrm{mg} \mathrm{L}^{-1}+$ Ethrel $^{\circledR} 1,5 \mathrm{~L} / \mathrm{ha}(5-15 \mathrm{~mm})$ & $22.4 \mathrm{~b}$ & $225.7 \mathrm{~b}$ & $100.6 \mathrm{~b}$ \\
\hline $\begin{array}{l}\text { Benzyladenine } 40 \mathrm{mg} \mathrm{L}^{-1}+\text { metamitron } 384 \mathrm{mg} \mathrm{L}^{-1} \\
(5-15 \mathrm{~mm})\end{array}$ & $29.7 \mathrm{~b}$ & $263.3 \mathrm{~b}$ & $112.4 \mathrm{a}$ \\
\hline $\begin{array}{l}\text { Benzyladenine } 40 \mathrm{mg} \mathrm{L}^{-1}+\text { metamitron } 768 \mathrm{mg} \mathrm{L}^{-1} \\
(5-15 \mathrm{~mm})\end{array}$ & $24.1 \mathrm{~b}$ & $206.5 \mathrm{~b}$ & $121.9 \mathrm{a}$ \\
\hline $\begin{array}{l}\text { Benzyladenine } 40 \mathrm{mg} \mathrm{L}^{-1}+\text { metamitron } 384 \mathrm{mg} \mathrm{L}^{-1} \\
(15-20 \mathrm{~mm})\end{array}$ & $40.9 \mathrm{a}$ & $530.3 \mathrm{a}$ & $76.2 \mathrm{c}$ \\
\hline Metamitron $384 \mathrm{mg} \mathrm{L}^{-1}(15-20 \mathrm{~mm})$ & $35.4 \mathrm{a}$ & $484.5 \mathrm{a}$ & $75.4 \mathrm{c}$ \\
\hline Hand thinning & $29.8 \mathrm{~b}$ & $241.8 \mathrm{~b}$ & $128.5 \mathrm{a}$ \\
\hline $\mathrm{VC}(\%)$ & 29.9 & 17.3 & 98.8 \\
\hline
\end{tabular}

Means followed by the same letter do not differ by the Scott Knott test at $5 \%$ probability. ns: not significant. * Fruit diameter at the time of application

TABLE 13- Production and number of fruit and plant and estimated yield of 'Fred Hough' cultivar in the year following the application of different thinning treatments chemical. Caçador-SC, 2015.

\begin{tabular}{|c|c|c|c|}
\hline Treatments & $\begin{array}{c}\text { Production of } \\
\text { fruits per plant } \\
\text { kg }\end{array}$ & $\begin{array}{l}\text { Number of } \\
\text { fruits per } \\
\text { plant }\end{array}$ & $\begin{array}{c}\text { Estimated } \\
\text { yield } \\
\text { t ha }^{-1}\end{array}$ \\
\hline Control (no thinning) & $20.6 \mathrm{c}$ & $174.5 \mathrm{c}$ & $51.5 \mathrm{c}$ \\
\hline Benzyladenine $40 \mathrm{mg} \mathrm{L}^{-1}(5-15 \mathrm{~mm}) *$ & $23.8 \mathrm{c}$ & $215.2 \mathrm{c}$ & $59.5 \mathrm{c}$ \\
\hline Metamitron $384 \mathrm{mg} \mathrm{L}^{-1}(5-15 \mathrm{~mm})$ & $33.4 \mathrm{~b}$ & $319.7 \mathrm{~b}$ & $83.5 \mathrm{~b}$ \\
\hline Metamitron $768 \mathrm{mg} \mathrm{L}^{-1}(5-15 \mathrm{~mm})$ & $53.2 \mathrm{a}$ & $517.2 \mathrm{a}$ & $133.3 \mathrm{a}$ \\
\hline Benzyladenine $40 \mathrm{mg} \mathrm{L}^{-1}+$ Ethrel $^{\circledR} 1,5 \mathrm{~L} / \mathrm{ha}(5-15 \mathrm{~mm})$ & $35.3 \mathrm{~b}$ & $376.8 \mathrm{~b}$ & $88.2 \mathrm{~b}$ \\
\hline Benzyladenine $40 \mathrm{mg} \mathrm{L}^{-1}+$ metamitron $384 \mathrm{mg} \mathrm{L}^{-1}(5-15 \mathrm{~mm})$ & $36.8 \mathrm{~b}$ & $349.3 \mathrm{~b}$ & $92.0 \mathrm{~b}$ \\
\hline Benzyladenine $40 \mathrm{mg} \mathrm{L}^{-1}+$ metamitron $768 \mathrm{mg} \mathrm{L}^{-1}(5-15 \mathrm{~mm})$ & $47.3 \mathrm{a}$ & $474.0 \mathrm{a}$ & $118.2 \mathrm{a}$ \\
\hline Benzyladenine $40 \mathrm{mg} \mathrm{L}^{-1}+$ metamitron $384 \mathrm{mg} \mathrm{L}^{-1}(15-20 \mathrm{~mm})$ & $13.2 \mathrm{c}$ & $111.8 \mathrm{c}$ & $33.0 \mathrm{c}$ \\
\hline Metamitron $384 \mathrm{mg} \mathrm{L}^{-1}(15-20 \mathrm{~mm})$ & $20.6 \mathrm{c}$ & $176.2 \mathrm{c}$ & $51.5 \mathrm{c}$ \\
\hline Hand thinning & $48.4 \mathrm{a}$ & $457.8 \mathrm{a}$ & $121.0 \mathrm{a}$ \\
\hline VC (\%) & 32.0 & 18.8 & 32.1 \\
\hline
\end{tabular}

Means followed by the same letter do not differ by the Scott Knott test at $5 \%$ probability. * Diameter of the fruit at the time of application.

* Fruit diameter at the time of application. 
TABLE 14- Fruit size percentage distribution $>65,56-64$ and $<55$ of 'Fred Hough' cultivar with different chemical thinning treatments. Caçador, SC, 2015.

\begin{tabular}{|c|c|c|c|}
\hline \multirow[b]{2}{*}{ Treatments } & \multicolumn{3}{|c|}{$\begin{array}{l}\text { Percentage of fruits according } \\
\text { to size }\end{array}$} \\
\hline & $\begin{array}{c}\geq 65 \\
\mathrm{~mm} \text { in } \\
\text { diameter }\end{array}$ & $\begin{array}{l}56 \mathrm{~mm} \text { to } \\
64 \mathrm{~mm} \text { in } \\
\text { diameter }\end{array}$ & $\begin{array}{l}\leq 55 \mathrm{~mm} \text { in } \\
\text { diameter }\end{array}$ \\
\hline Control (no thinning) & $2.9 \mathrm{c}$ & $29.7 \mathrm{~b}$ & $67.4 \mathrm{a}$ \\
\hline Benzyladenine $40 \mathrm{mg} \mathrm{L}^{-1}(5-15 \mathrm{~mm})^{*}$ & $5.6 \mathrm{c}$ & $31.3 \mathrm{~b}$ & $63.1 \mathrm{a}$ \\
\hline Metamitron $384 \mathrm{mg} \mathrm{L}^{-1}(5-15 \mathrm{~mm})$ & $25.0 \mathrm{~b}$ & $41.6 \mathrm{a}$ & $33.4 \mathrm{~b}$ \\
\hline Metamitron $768 \mathrm{mg} \mathrm{L}^{-1}(5-15 \mathrm{~mm})$ & $37.0 \mathrm{~b}$ & $40.9 \mathrm{a}$ & $22.1 \mathrm{c}$ \\
\hline Benzyladenine $40 \mathrm{mg} \mathrm{L}^{-1}+$ Ethrel $^{\circledR} 1,5 \mathrm{~L} / \mathrm{ha}(5-15 \mathrm{~mm})$ & $26.9 \mathrm{~b}$ & $36.1 \mathrm{a}$ & $36.9 \mathrm{~b}$ \\
\hline Benzyladenine $40 \mathrm{mg} \mathrm{L}^{-1}+$ metamitron $384 \mathrm{mg} \mathrm{L}^{-1}(5-15 \mathrm{~mm})$ & $49.7 \mathrm{a}$ & $26.2 \mathrm{~b}$ & $24.1 \mathrm{c}$ \\
\hline Benzyladenine $40 \mathrm{mg} \mathrm{L}^{-1}+$ metamitron $768 \mathrm{mg} \mathrm{L}^{-1}(5-15 \mathrm{~mm})$ & $39.5 \mathrm{~b}$ & $42.5 \mathrm{a}$ & $18.0 \mathrm{c}$ \\
\hline Benzyladenine $40 \mathrm{mg} \mathrm{L}^{-1}+$ metamitron $384 \mathrm{mg} \mathrm{L}^{-1}(15-20 \mathrm{~mm})$ & $3.2 \mathrm{c}$ & $32.8 \mathrm{~b}$ & $64.0 \mathrm{a}$ \\
\hline Metamitron $384 \mathrm{mg} \mathrm{L}^{-1}(15-20 \mathrm{~mm})$ & $2.6 \mathrm{c}$ & $24.1 \mathrm{~b}$ & $73.4 \mathrm{a}$ \\
\hline Hand thinning & $58.2 \mathrm{a}$ & $31.1 \mathrm{~b}$ & $10.7 \mathrm{~d}$ \\
\hline VC (\%) & 29.6 & 19.9 & 17.2 \\
\hline
\end{tabular}

Means followed by the same letter do not differ by the Scott Knott test at $5 \%$ probability. * Diameter of the fruit at the time of application.

* Fruit diameter at the time of application.

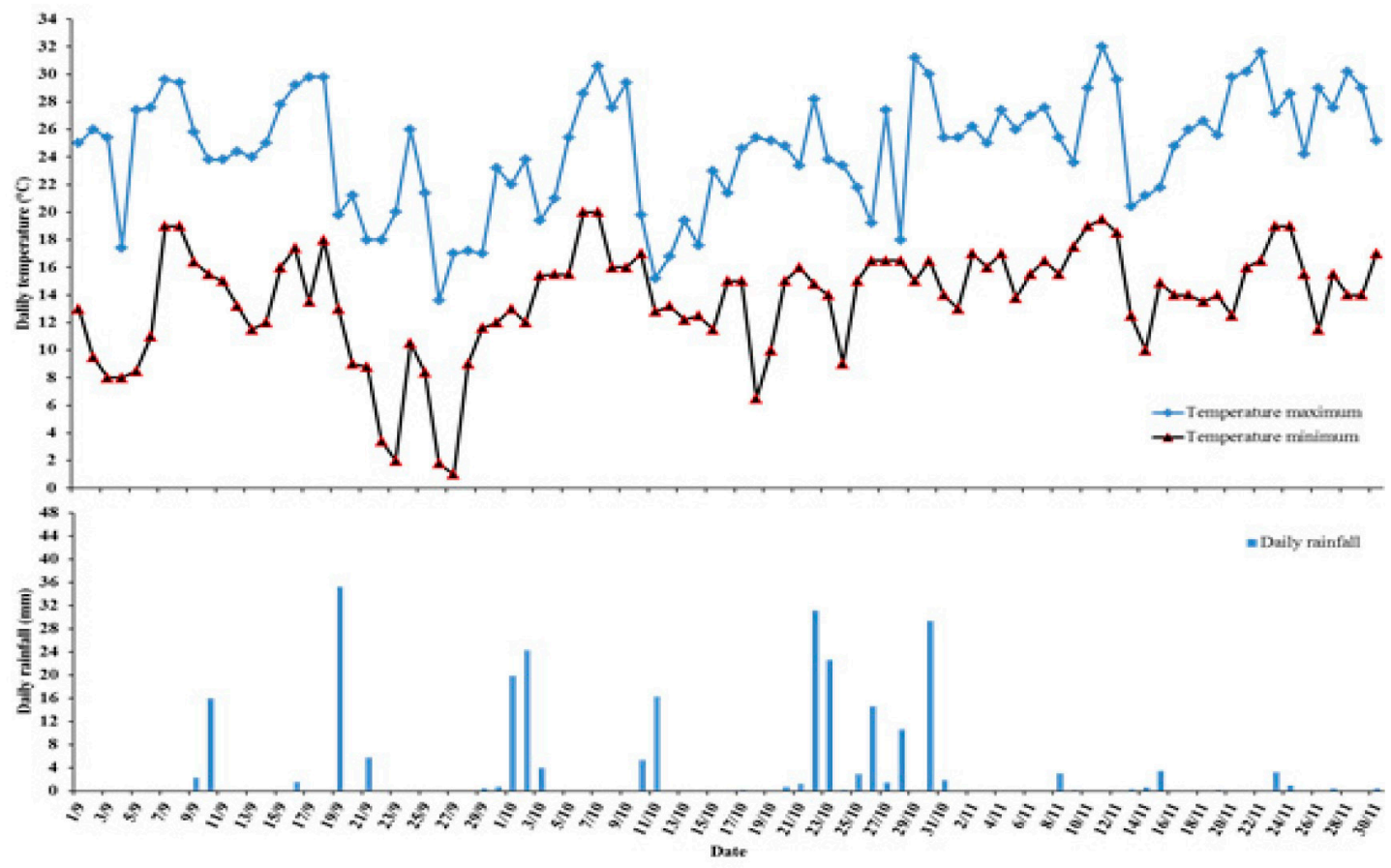

FIGURE 1- Maximum and minimum daily temperatures and daily rainfall during the thinning efficiency evaluation period in 'Fuji', 'MaxiGala' and 'Fred Hough' apple cultivars. Caçador-SC 2012. 


\section{REFERENCES}

BANGERTH, F. Flower induction in perennial fruit trees:still an enigma? Acta Horticulturae, The Hague, n.727, p.177-196, 2006.

BASAK, A. Eficiency of fruitlet thinning in apple "Gala Must" by use of metamitron and artificial shading. Journal of Fruit and Ornamental Plant Research, Philadelphia, v.19, p.51-62, 2011.

BRUNNER, P. Impact of metamitron as a thinning compound on apple plants. Acta Horticulturae, Orlando, v.1042, p.173-181, 2014.

BYERS, R. E. and CARBOUGH, D. H. Effect of the chemical thinning sprays on the apples fruit set. HortTechnology, Alexandria, v.1, p.41-48, 1991.

DECKERS, T.; SCHOOFS, H.; VERJANS, W. Looking for solutions for chemical fruit thinning on apple. Acta Horticulturae, The Hague, v.884, p.237-243, 2010.

FALLAHI, E.; KIESTER, M.J.; FALLAHI, B.; GREENE, D.W. Influence of potentially new post-bloom thinners on apple fruit thinning. XII international symposium plant bioregulators in fruit production. Acta Horticulturae, The Hague, v.1042, p.183-188, 2014.

FERREIRA, D.F. SISVAR - programa estatístico. Versão 5.3 (Build 75). Lavras: Universidade Federal de Lavras, 2010.

FRANCESCATTO, P. Desenvolvimento das estruturas reprodutivas da macieira (Malus domestica Borkh.) sob diferentes condições climáticas - da formação das gemas a colheita dos frutos. 239f. Tese (Doutorado)-Centro de Ciências Agrárias, Universidade Federal de Santa Catarina, , Florianópolis, 2014.

GABARDO, G.C. Metamitron como alternativa no raleio químico de pós-floração da macieira. 2015. Dissertação (Mestrado) - Centro de Ciências Agroveterinárias, Universidade do Estado de Santa Catarina, Lages, 2015.

GREENE, D.W. Chemicals, timing, and Environmental Factors Involved in Thinner Efficacy on Apple. HortScience, Alexandria, v.37, p.477-481, 2002.
GREENE, D.W. Effects of repeated yearly application of chemical thinners on 'McIntosh' apples. HortScience, Alexandria, v.40, n.2, p.401403, 2005.

GREENE, D.W. Use of metamitron alone and in combination with 6-benzyladenine for thinning apples. Acta Horticulturae, Orlando, v.1042, p.167172,2014

GREENE, D.W., AUTIO, W.R., ERF, J. A.; ZHONGYUAN, Y.M. Mode of action of benzyladenine when used as a chemical tinner. Journal of the American Society Horticultural Science, Alexandria, v.117, p.775 - 779, 1992.

GREENE, D.W.; AUTIO, W.R.; MILLER, P. Thinning activity of benzyladenine on several apple cultivars. Journal of the American Society Horticultural Science, Alexandria, v.115, p.390400, 1990.

LAFER, G. Effects of chemical thinning with metamitron on fruit set, yield and fruit quality of 'Elstar'. Acta Horticulturae, Bologna, v.884, p.531$536,2010$.

MCARTNEY, S.J.; OBERMILLER, J.D. Use of shading and PSII inhibitor metamitron to investigate the relationship between carbohydrate balance and thinner activity in apples. Acta Horticulturae, The Hague, v.1042, p.27-31, 2014.

MCLAUGHLIN, J.; GREENE, D.W. Effects of BA, GA 4+7, and daminozide on fruit set, fruit quality, vegetative growth, flower initian, and flower quality of 'Golden Delicius' apple. Journal of the American Society Horticultural Science, Alexandria, v.109, p.34 - 39, 1984.

REGINATO, G.; OSÓRIO, H.; NAVARRETE, J. A single metamitron spray thinner 'Brookfield Gala' apples as effectively as a program of treatments based on NAA, carbaryl ande BA. Acta Horticulturae, The Hague, v.1058, p.397-404, 2014.

ROBINSON, T.L.; LAKSO, A.N.Predicting chemical thinner response with a carbohydrate model. Acta Horticulturae, The Hague, v.903, p.743-750, 2011. 
SILVA, C. Utilização de vários agentes de monda química em macieira, em período pré-floral, floral e pós-floral, numa utilização isolada ou sequencial, nas variedades 'Lysgolden', 'Golden Smothee', 'Royal Gala' e 'Fuji'. In: SIMPÓSIO NACIONAL DE FRUTICUlTURA, 3., 2014. Vila Real. Actas Portuguesas de Horticultura...p-9-20.

STERN, R.A. The photosynthesis inhibitor metamitron is an effective fruitlet thinner for 'Gala' apple in the warm climate of Israel. Scientia Horticulturae, New York, v.178, p.163-167, 2014.

WISMER, P.T.; PROCTOR, J.T.A.; ELFVING, D.C. Benzyladenine effects cell division and cell size during apple fruit thinning. Journal of the American Society Horticultural Science, Alexandria, v.120, n.5, p.802-807, 1995.
YUAN, R.; GREENE, D.W. Benzyladenine as a chemical thinner for McIntosh apples. I. Fruit thinning effects and associated relationships with photosynthesis, assimilate translocation, and nonstructural carbohydrates. Journal of the American Society for Horticultural Science, Alexandria, v.125, p.169 - 176, 2000a.

YUAN, R.; GREENE, D.W. Benzyladenine as chemical thinner for 'McIntosh' apples. II. Effect of benzyladenine, bourse shoot tip removal, and life number on fruit retention Journal of the American Society of Horticultural Science, Alexandria, v.125, p.177-182, 2000b. 